\title{
Genotype $x$ environment interaction on post-weaning performance and carcass in beef cattle
}

\section{Interação genótipo $x$ ambiente sobre características de desempenho e de carcaça de bovinos de corte}

\author{
Leandro Lunardini Cardoso ${ }^{1 *}$; Patrícia Biegelmeyer ${ }^{1}$; Fernando Flores Cardoso ${ }^{2}$
}

\begin{abstract}
We analyzed average daily gain from weaning to yearling (ADG), yearling weight (YW), rib eye area, and subcutaneous fat thickness of 91 Angus, Hereford, Caracu, and Nellore cattle, and their crosses. The animals were split into two grazing groups: improved natural grassland $(n=47)$ and natural grassland (n $=44$ ). The environment was found to influence all traits, and the highest measures of performance were observed in improved natural grassland. The genetic group $\mathrm{x}$ environment interaction was verified only for $\mathrm{ADG}$ and $\mathrm{YW}(\mathrm{P}<0.05)$. We found the best performance trait averages for crossbreeds of Bos taurus and Bos indicus. In addition, we found genetic $\mathrm{x}$ environment interaction effects in growing traits and Longissimus muscle area between the evaluated genotype groups. Finally, we found that between the evaluated genotype groups, subcutaneous adipose fat was not influenced by the environment.
\end{abstract}

Key words: Beef cattle. Carcass. Crossbreeding. Environment effect. Genotype. Weaning.

\section{Resumo}

Foram analisadas as características de ganho de peso médio diário da desmama ao sobreano (GMD), peso ao sobreano (PS), área do músculo longissimus (AOLUS) e espessura de gordura subcutânea por ultrassom (EGSUS) de 91 animais das raças Angus, Hereford, Caracu e Nelore e seus cruzamentos. Destes, 47 animais foram manejados em pastagem natural melhorada e 44 animais em campo natural do Bioma Pampa. Todas as características foram influenciadas pelo ambiente, sendo que os melhores desempenhos foram observados no ambiente constituído pela pastagem natural melhorada. A interação grupo genético $\mathrm{x}$ ambiente foi verificada no GMD e no PS $(\mathrm{P}<0,05)$. As maiores médias das características analisadas pertenceram a produtos do cruzamento entre Bos taurus e Bos indicus. Houve efeito da interação genótipo x ambiente nas características de crescimento e de área do músculo longissimus entre os grupos genéticos avaliados $(\mathrm{P}<0,05)$. A deposição de tecido adiposo subcutâneo não foi influenciada pelo ambiente de criação entre os grupos genéticos estudados.

Palavras-chave: Cruzamentos. Efeito ambiental. Genótipo. Pastagem. Sobreano. Ultrassom. Terminação.

\footnotetext{
${ }^{1}$ Discentes de Pós-Doutorado em Bioinformática e Estatística Genômica, EMBRAPA Pecuária Sul, Bagé, RS, Brasil. E-mail: lunardini.cardoso@ufrgs.br; patriciabiegel@gmail.com

2 Pesquisador, Embrapa Pecuária Sul, Bagé, RS, Brasil. E-mail: fernando.cardoso@embrapa.br

* Author for correspondence 


\section{Introduction}

The identification of breeds and crosses between breeds that show improved weight gain speed, high final weight, and high yields of boneless beef finishing precocity, in addition to high environmental adaptability, increases the profitability of beef cattle in the production system. Considering the type of cross used is one method to increase the productivity of production systems, because the advantage of heterosis and complementarity between breeds is considered when combining the genetic potential of specialized European breeds in meat production with the hardiness and adaptability of Zebu (QUEIROZ et al., 2009).

The phenotype of an animal is a result of its genotype, environment, and genotype x environment interaction (FALCONER; MACKAY, 1997). However, in view of the environmental diversity of cattle farming systems in Brazil that provide different forms of phenotypic expression for the same genotype, there is difficulty in identifying and selecting genetically superior individuals for certain environments (LOPES et al., 2008).

Genetic groups (GGs) are subject to significant environmental effects, as increase the Nelore gene proportions (TEIXEIRA et al., 2006). Similarly, the breed composition and proportion of Zebu genes influence the carcass in terms of meat quality, carcass weight, subcutaneous fat thickness, and Longissimus muscle area (CROUSE et al., 1989). Therefore, knowledge of productive breeds and the potential of their crosses, as well as the interaction between the genotype and the environment, can improve the efficiency of livestock production. The objective of this study was to determine the effect of genotype $\mathrm{x}$ environment interaction on the postweaning growth and carcass traits of pure breeds Angus, Hereford, Caracu, and Nellore cattle, and their crosses, when finished on natural or improved natural grassland in the Pampa Biome.

\section{Material and Methods}

We measured the performance of 91 animals born between 2006 and 2008. The animals originated from crossing Angus (AN), Hereford (HH), and Nelore (NENE) cows with AN (ANAN), HH (ANHH), NE (ANNE), and Caracu (ANCR) bulls in an incomplete diallel design that performs all possible crosses between $n$ number of progenitors. We conducted the study at the Embrapa Cattle South Bagé-RS, Brazil. From birth to weaning, all the animals were raised under the same feeding conditions of the natural grassland, characterized as Pampa Biome. After weaning, 47 animals were transferred to improved natural grassland (referred to as A1 Environment) with ryegrass (Lolium multiflorum) and red clover (Trifolium pratense L.). The remaining 44 animals continued on the natural grassland (referred to as A2 environment). The initial body weight (BW) of animals at an average age of $21.10 \pm 0.99$ mo on the A1 environment was $354.70 \pm 54.67 \mathrm{~kg}$, while that of animals at an average age of $20.80 \pm 0.80 \mathrm{mo}$ on the A2 environment was $348.61 \pm 55.28 \mathrm{~kg}$. The animals were managed under continuous grazing for 125 days until the evaluation date by ultrasound, and slaughtered at an average age of $25.26 \pm 0.99$ mo in the A1 environment and at $24.96 \pm 0.80 \mathrm{mo}$ in the A2 environment. We measured the weaning weight (WW) during the weaning period, after the animals were separated from their mothers and after $12 \mathrm{~h}$ of fasting, without both food and water. We obtained the yearling weight (YW) by weighing the animals after $16 \mathrm{~h}$ of fasting, without both food and water. We calculated the average daily gain (ADG) from the initial weight (IW) and yearling weight (YW) by using the equation: $\mathrm{ADG}=(\mathrm{YW}-\mathrm{IW}) /$ days, where days describe the number of testing days.

The rib eye area between the 12th and 13th ribs (ULMA) and fat thickness between the 12th and 13th ribs (UFAT) in yearlings were measured using ultrasound images. We obtained and recorded ultrasound images for later analysis by using Auskey System software for Windows ${ }^{\circledR} 5.0$ (LIU, 
1997). The ultrasound images were collected using a head unit of the brand model ALOKA SSD500 (Corometrics Medical Systems, Wallingford, CT) with a $3.5 \mathrm{MHz}$ linear array transducer and $17.2 \mathrm{~cm}$ of length UST-5044 model.

The We calculated averages the mean and standard deviation by using the SAS Proc Means function and GG means by the method of least squares means by using the SAS Proc Mixed function (SAS v. 9.3, Inst. Inc., Cary, NC). Further, we compared adjusted means by using the Tukey test, adopting the following mathematical model:

$$
\begin{aligned}
Y_{i j k l}=\mu & +A_{i}+G_{j}+C_{k}+(G \times C)_{k}+ \\
& +\beta_{1} D_{l}+\beta_{2} P_{l}+\varepsilon_{i j k l}
\end{aligned}
$$

where $Y_{i j k l}$ is the set of dependent variables (ADG, YW, ULMA, and UFAT); $\mu$ is the general average; $A i$ is the fixed effect of the ith year of birth; $G j$ is the fixed effect of the $j$-th $\mathrm{GG}$; $C k$ is the fixed effect of the $k$-th diet; $(G \times C) j k$ is the effect of the interaction between $\mathrm{GG}$ and diet; $\beta 1$ is the regression coefficient at the age of the $l$ animal $\left(I D_{l}\right) ; \beta 2$ is the regression coefficient of the initial weight $l(P I)$; and $\varepsilon_{i j k l}$ is the residual effect.

We considered four levels of GG factors in the analysis, where the product of AN $\mathrm{x} \mathrm{HH}$ crosses is composed of the same group of animals in $\mathrm{HH} \mathrm{x}$ $\mathrm{AN}$ (AN x HH), as did the crosses AN x NE and NE $x$ AN, which comprised the same GG (NE x AN). We adopted this procedure to increase the number of observations by analyzed genotypes. In order to test the overall effect of crossing in relation to $\mathrm{AN}$, base and diallel crosses of AN x HH, AN x CR, and $x$ AN x NE were compared and contrasts between means or mean class of GGs were assessed.

\section{Results and Discussion}

The environment had a significant effect on all traits, with the best performance measures recorded on the A1 environment (Table 1). The ADG is a measure of the rate of live weight accumulation and can be used as a measure of the animal's growth rate (CASAS; CUNDIFF, 2006), where the nutritional plan has been shown to significantly affect the daily live weight gain and growth rate (BERG; BUTTERFIELD, 1976). Here, we show that the ADG rate was higher in the A1 environment (0.359 $\mathrm{kg} / \mathrm{d})$ than in the A2 environment $(-0.044 \mathrm{~kg} / \mathrm{d})$. In summary, we found environmental effects when animals were reared in a more restrictive nutritional plan, performing worse than those provided with better feeding conditions.

We found that the Longissimus muscle area was higher $(\mathrm{P}<0.05)$ for animals raised in the A1 environment than in the $\mathrm{A} 2$ environment (Table 1), demonstrating that the environment influenced the development of muscular tissue. In contrast to our results, Lage et al. (2012) found that in a feedlot with two different levels of concentrate in the diet, animals did not show significantly different Longissimus muscle area based on nutritional plan. Moreover, Ferreira et al. (2011) and Devincenzi et al. (2012) found no significant differences in Longissimus muscle area in animals raised under conditions (A1 vs. A2 environment) similar to this study. We suggest that our results may be influenced by a negative gain imposed by the $\mathrm{A} 2$ environment in relation to the ADG in the A1 environment. 
Table 1. Number of animals (n), least square means \pm standard error for post weaning gain (ADG, $\mathrm{kg} / \mathrm{day}$ ), yearling weight (YW, $\mathrm{kg}$ ), ultrasound Longissimus muscle area (ULMA, $\mathrm{cm}^{2}$ ) and ultrasound subcutaneous fat (UFAT, $\mathrm{mm}$ ) in different environments.

\begin{tabular}{lcccccc}
\hline \multicolumn{1}{c}{ Environment } & & $\mathrm{n}$ & $\begin{array}{c}\mathrm{ADG}, \\
\mathrm{kg} / \text { day }\end{array}$ & $\begin{array}{c}\text { YW, } \\
\mathrm{kg}\end{array}$ & $\begin{array}{c}\text { ULMA, } \\
\mathrm{cm}^{2}\end{array}$ & $\begin{array}{c}\text { UFAT } \\
(\mathrm{mm})\end{array}$ \\
\hline Improved natural grassland & $\mathrm{A} 1$ & 47 & $0.359 \pm 0.021^{\mathrm{a} *}$ & $399.0 \pm 2.642^{\mathrm{a}}$ & $49.85 \pm 0.837^{\mathrm{a}}$ & $3.57 \pm 0.154^{\mathrm{a}}$ \\
Natural grassland & A2 & 44 & $-0.036 \pm 0.020^{\mathrm{b}}$ & $349.19 \pm 2.541^{\mathrm{b}}$ & $37.82 \pm 0.079^{\mathrm{b}}$ & $2.07 \pm 0.146^{\mathrm{b}}$ \\
\hline
\end{tabular}

* Means followed by distinct letters, in the same column, are significantly different $(\mathrm{P}<0.05)$.

The environment also influenced the UFAT (Table 1). We suggest that the small variation in UFAT within the environment may be associated with a low dietary energy concentration typically found on pasture, which generally results in a slower rate of body fat deposition (OWENS et al., 1993). According to the Brazilian System of Classification and Carcass Grading (BRASIL, 2004), fat thickness between 1 and $3 \mathrm{~mm}$ are classified as scarce, and 3 and $6 \mathrm{~mm}$ as median. Animals raised in the A2 environment with 125 days of grazing did not deposit sufficient subcutaneous adipose tissue to reach the median classification, and therefore, did not achieve the required fat thickness for adequate thermal protection against the cold during post-slaughter cooling. Fat thermal protection reduces sarcomere shortening and overlap between the myosin and actin filaments causing meat hardening, as well as reduction of drip loss. Furthermore, carcasses without thermal protection in pre-rigor-mortis still show rapid temperature reduction in the pre-rigor phase, resulting in cold shortening (LAWRIE, 2004). According to Berg and Butterfield (1976), adipose tissue is the most variable in relation to deposition and distribution and is influenced by an animal's age and nutritional plan. In a natural environment, animals seek their food, causing high energy expenditure and low fat deposition; however, when the same animals are moved to conditions with abundant food, their metabolism changes (MERSMANN, 1990). Thus, in environments where the diet is limited and/or the energy requirements are high, the increase in adipose tissue is minimized (ETHERTON; WALTON, 1986). Here, we observed a similar effect, where animals raised in the A2 environment had higher deposition of subcutaneous fat than that in animals raised in the more restrictive conditions of the A1 environment. Therefore, animals raised in the A2 environment were able to achieve the required fattening for a median classification at slaughter at the same age and grazing time as that of animals raised in the A1 environment. The ADG was similar among GGs within environments (Table 2).

Table 2. Least square means \pm standard error for post weaning gain (ADG, $\mathrm{kg} / \mathrm{dia}$ ) and yearling weight (YW, $\mathrm{kg}$ ) for genetics groups and environments.

\begin{tabular}{lcccc}
\hline Genetic Group $^{1}$ & ADG, kg/day & \multicolumn{2}{c}{ YW, kg } \\
\hline $\mathrm{n}(\mathrm{A} 1 \mid \mathrm{A} 2)^{2}$ & Environment 1 & Environment 2 & Environment 1 & Environment 2 \\
\hline ANAN $(7 \mid 8)$ & $0.352 \pm 0.042^{\mathrm{a} *}$ & $-0.098 \pm 0.038^{\mathrm{a}}$ & $398.92 \pm 5.23^{\mathrm{a}}$ & $342.20 \pm 4.76^{\mathrm{b}}$ \\
ANCR $(12 \mid 11)$ & $0.362 \pm 0.031^{\mathrm{a}}$ & $-0.056 \pm 0.033^{\mathrm{a}}$ & $399.36 \pm 3.90^{\mathrm{a}}$ & $346.70 \pm 4.19^{\mathrm{b}}$ \\
ANHH $(10 \mid 10)$ & $0.394 \pm 0.036^{\mathrm{a}}$ & $-0.099 \pm 0.035^{\mathrm{a}}$ & $404.26 \pm 4.49^{\mathrm{a}}$ & $340.92 \pm 4.44^{\mathrm{b}}$ \\
ANNE $(12 \mid 10)$ & $0.379 \pm 0.036^{\mathrm{a}}$ & $0.045 \pm 0.033^{\mathrm{a}}$ & $401.48 \pm 4.49^{\mathrm{a}}$ & $359.45 \pm 4.15^{\mathrm{a}}$ \\
NENE $(6 \mid 5)$ & $0.304 \pm 0.047^{\mathrm{a}}$ & $0.026 \pm 0.055^{\mathrm{a}}$ & $392.46 \pm 5.90^{\mathrm{a}}$ & $356.67 \pm 6.81^{\mathrm{ab}}$ \\
\hline
\end{tabular}

${ }^{1}$ ANAN = Angus; ANCR = Angus $\mathrm{x}$ Caracu; ANHH = Angus $\mathrm{x}$ Hereford and HHAN; ANNE = Angus $\mathrm{x}$ Nelore and Nelore $\mathrm{x}$ Angus; $\mathrm{NEHH}=$ Nelore $\mathrm{x}$ Hereford; $\mathrm{NENE}=$ Nelore. ${ }^{2} \mathrm{n}(\mathrm{A} 1 \mid \mathrm{A} 2)$ numbers of nimal in environment A1 and A2. * Means followed by distinct letters, in the same column, are significantly different $(\mathrm{P}<0.05)$. 
Beaver et al. (1989) did not find significant differences in post-weaning ADG between Angus and Brangus breeds raised in the same environment. Likewise, Casas et al. (2010) did not find a breed effect on the ADG in Angus, Hereford, and Brangus when raised under the same nutritional plan. However, Casas and Cundiff (2006) reported a significant GG effect on post-weaning ADG in Angus, Hereford, Holstein, Norwegian Red, Red and White Swedish, and Japanese Wagyu, where the difference between sexes (intact male vs. female) was greater than the breed effect.

Was not observed genotype $\mathrm{x}$ environment interaction effect in YW between the GGs within the A1 environment (Table 2). Casas et al. (2010) did not find significant differences in the breed effect on weight at slaughter of Angus, Hereford, and Brangus breeds. According to Dickerson (1962), genetic differences can only be observed if the environment allows gene expression of the trait of interest. We suggest that the low gain rate in this study was not sufficient for maximal expression of ADG, thereby decreasing the YW variability between the GGs in the more favorable environment. However, we found a significant interaction between GGs and the environment for the YW trait in the A2 environment (Table 2). The GG ANNE was heavier than NENE, ANCR, ANAN, and ANHH, respectively. These data are in accordance with those reported by Prado et al. (2004), who showed that Nellore x Limousin crossbreeds had a greater final weight because of a greater degree of heterosis in YW, as well as the results of Kippert et al. (2008), who showed that Nellore $1 / 2 \times 1 / 2$ Angus crossbreeds had higher YW. Furthermore, Brown et al. (2000) and Teixeira et al. (2006) showed that heterosis effects were more pronounced when exposed to greater stresses.

Animals ANNE showing greater longissimus muscle $(\mathrm{P}<0.05)$ than that in the other GGs (Table 3).

Table 3. Least square means \pm standard error for Longissimus muscle area (ULMA, $\mathrm{cm}^{2}$ ) and fat thickness (UFAT, $\mathrm{mm}$ ) by ultrasound in different genetic groups.

\begin{tabular}{lll}
\hline \multicolumn{1}{c}{$\begin{array}{c}\text { Genétic Group } \\
(\mathrm{n})^{2}\end{array}$} & \multicolumn{2}{c}{ Trait } \\
\cline { 2 - 3 } & ULMA $\left(\mathrm{cm}^{2}\right)$ & UFAT $(\mathrm{mm})$ \\
\hline ANAN (14) & $41.91 \pm 1.23^{\mathrm{b}}$ & $2.92 \pm 0.22^{\mathrm{b}}$ \\
ANCR (23) & $43.58 \pm 0.98^{\mathrm{b}}$ & $2.46 \pm 0.18^{\mathrm{b}}$ \\
ANHH (20) & $41.85 \pm 1.12^{\mathrm{b}}$ & $2.55 \pm 0.20^{\mathrm{b}}$ \\
ANNE (22) & $48.35 \pm 1.06^{\mathrm{a}}$ & $3.26 \pm 0.19^{\mathrm{a}}$ \\
NENE (11) & $43.49 \pm 1.63^{\mathrm{b}}$ & $2.91 \pm 0.30^{\mathrm{b}}$ \\
\hline
\end{tabular}

${ }^{1}$ ANAN $=$ Angus; ANCR $=$ Angus $\mathrm{x}$ Caracu; ANHH $=$ Angus $\mathrm{x}$ Hereford and HHAN; ANNE $=$ Angus $\mathrm{x}$ Nelore and Nelore $\mathrm{x}$ Angus; $\mathrm{NEHH}=$ Nelore $\mathrm{x}$ Hereford; NENE $=$ Nelore $^{2} \mathrm{n}(\mathrm{A} 1 \mid \mathrm{A} 2)$ numbers of nimal in environment A1 and A2. ${ }^{*}$ Means followed by distinct letters, in the same column, are significantly different $(\mathrm{P}<0.05)$.

Casas et al. (2010) found significant differences $(\mathrm{P}<0.05)$ between ANNE cattle in relation to ANAN and Hereford, while Hamlin et al. (1995) found a significant effect of bull and cow breeds $(\mathrm{P}<0.05)$ in Longissimus muscle area. Berg and Butterfield (1976) suggest that the age, breed, weight, sex, nutrition, and other factors influence the muscular tissue growth of the animal, while Te Pas et al. (2004) suggested that approximately twothirds of the standard deviation of the phenotypic variation in the size and number of muscle fibers is attributable to genetics. Here, the significantly higher longissimus muscle area in Nellore and British taurine crossbreeds compared to the GGs without zebu gene contribution may be explained by the maximum additive effect of heterosis on muscle development of the bulls from the Bos indicus $\mathrm{x}$ Bos taurus crosses.

The GG ANNE produced animals with greater $\operatorname{UFAT}(3.26 \pm 0.19 \mathrm{~mm})$ than that in GGs of adapted 
and pure breeds (Table 3). Prado et al. (2004) demonstrated the GG effect on fat deposition in Nellore and Brangus animals raised in the same environment. Likewise, Perotto et al. (2008) attributed the production of more young steers with higher carcass weight and better fattening traits to the ANAN x NENE cross. In contrast, Euclides Filho et al. (1997) did not report differences in fat deposition with different diets containing $100 \%$ forage and the inclusion of $40 \%$ and $60 \%$ concentrate in Nellore and their crosses, while NENE animals were similar to the GGs of European origin $(\mathrm{P}>0.05)$. According to the NRC (2001), fat deposition depends on the GG, body weight, intensity of daily weight gain, maturity, and diet energy density. Therefore, the difference in the expression of the trait in this study may be assigned by the maximum heterosis in the GG ANAN x NENE. These results indicate that the heterosis effect can be utilized for obtaining the finishing precocity in the ANAN x NENE cross.

We present no evidence of a genotype $\mathrm{x}$ environment interaction in ADG in ANAN versus ANCR, ANHH, and ANNE crosses, while the means did not differ significantly $(\mathrm{P}>0.05)$ between the different raising environments (Table 4). Genotypes that present high variability between and within environments are "plastic" and those with little variability are "robust," while phenotypic plasticity is related to a genotype $\mathrm{x}$ environment interaction (DE JONG; BIJMA, 2002). As a result, if animals of different genotypes have significantly different performance in relation to the environment, it provides evidence for a genotype $\mathrm{x}$ environment interaction. However, in this study we did not observe this effect in ADG between genotypes.

Table 4. Contrasts between the average genetic groups in average daily gain (ADG, kg / day) in different environments.

\begin{tabular}{|c|c|c|c|c|}
\hline \multirow{2}{*}{$\frac{\text { Contrast }^{1}}{\text { Genetic Group }}$} & \multicolumn{2}{|c|}{ ADG, kg/dia } & \multicolumn{2}{|c|}{ YW, kg } \\
\hline & A1 & A2 & A1 & $\mathrm{A} 2$ \\
\hline$\frac{\text { Crossed AN x AN }}{\text { ANCR } \mid \text { ANHH } \mid \text { ANNE vs. ANAN }}$ & 0.026 & 0.061 & 2.783 & 6.830 \\
\hline$\frac{\text { Adapted AN x British }}{\text { ANCR|ANNE vs. ANHH }}$ & -0.024 & $0.094 *$ & -3.840 & $12.153^{*}$ \\
\hline$\frac{\text { Bos indicus adaptaded x Bos taurus adapted }}{\text { ANNE vs. ANCR }}$ & $0.093^{*}$ & 0.0187 & 10.882 & 1.503 \\
\hline
\end{tabular}

${ }^{1}$ ANAN = Angus; ANCR $=$ Angus $\times$ Caracu; ANHH= Angus $\times$ Hereford; ANNE= Angus $\times$ Nelore; $\mathrm{A} 1=$ improved natural grassland; $\mathrm{A} 2=$ natural grassland $* \mathrm{P}<0, .5$.

The ADG of ANCR and ANNE vs. ANHH in the A1 environment did not differ significantly ( $P$ $<0.05)$. However, in the A2 environment, with the most restricted diet, the ADG was significantly affected by the environment $(\mathrm{P}<0.05)$. We found that the Angus x Caracu and Angus x Nellore crosses had higher ADG than did the Angus $x$ Hereford cross, showing a genotype $\mathrm{x}$ environment interaction. The GG ANNE had a greater ADG $(\mathrm{P}<$ 0.05 ) than ANCR in the A1 environment. In contrast, we also found no significant difference between the GGs (ANNE vs. ANCR) in the A2 environment. Likewise, previous studies have shown a genotype $\mathrm{x}$ environment interaction effect on ADG by using the average environmental effect as an environmental variable (CORREAA et al., 2007; CARDOSO et al., 2011).

We did not observe a GG effect on the YW within and between environments $(\mathrm{P}>0.05)$ in ANAN, ANCR, ANHH, and ANNE (Table 4), and there were no genotype $\mathrm{x}$ environment interaction effects on the YW in these GGs. The means contrast between ANCR and ANNE vs. $\mathrm{ANHH}$ in the Al environment was not significant $(\mathrm{P}<0.05)$. However, adapted GGs (ANCR and 
ANNE) were superior to the British GG (ANHH) in the A2 environment, promoting $12.15 \mathrm{~kg}$ more YW in the A2 environment. Teixeira et al. (2006) found a greater effect of genotype $\mathrm{x}$ environment interaction on the YW in steers in environments that promote lower average YW, while Barlow et al. (1981) suggest that restrictive environments promote greater effects of heterosis $\mathrm{x}$ environment interactions.

In all contrasts (Table 5), the longissimus muscle area was influenced by cross $(\mathrm{P}<0.05)$. The contrast between the groups crossed with Angus (ANCR, ANHH, and ANNE) showed that ULMA was 2.68 $\mathrm{cm}^{2}$ higher than that in pure animals (ANAN). The contrast between ANCR and ANNE showed a 4.12 $\mathrm{cm}^{2}$ gain in ULMA than that in ANHH. The contrast between ANNE and ANCR showed the largest increases in the Longissimus muscle, with an area of $8.12 \mathrm{~cm}^{2}$. Heterosis effects increase according to increases in the genetic distance between breeds (VAZ; RESTLE, 2001; SIQUEIRA et al., 2009). Here, increased heterosis effects were demonstrated for the major genetic distance between Angus and Nellore breeds with regard to taurine and taurine adapted breeds, providing the high heterosis effects in Nellore $x$ Angus cross that resulted in greater accumulation rates in muscular tissue.

Table 5. Contrast between genetic groups for longissimus muscle area (ULMA, $\mathrm{cm}^{2}$ ) and fat thickness (UFAT, mm) by ultrasound in different genetic groups.

\begin{tabular}{|c|c|c|}
\hline$\underline{\text { Contrast }}^{1}$ & ULMA, $\mathrm{cm}^{2}$ & UFAT, mm \\
\hline$\frac{\text { Crossed AN x AN }}{\text { ANCR } \mid \text { ANHH|ANNE vs. ANAN }}$ & $2.68 *$ & -0.06 \\
\hline$\frac{\text { Adapted AN x British }}{\text { ANCR|ANNE vs. ANHH }}$ & $4.12 * * *$ & 0.11 \\
\hline$\frac{\text { Bos indicus adaptaded x Bos taurus adapted }}{\text { ANNE vs. ANCR }}$ & $8.12 * *$ & -0.05 \\
\hline
\end{tabular}

${ }^{1} \mathrm{ANAN}=$ Angus; $\mathrm{ANCR}=$ Angus $\times$ Caracu; $\mathrm{ANHH}=$ Angus $\mathrm{x}$ Hereford; ANNE $=$ Angus $\mathrm{x}$ Nelore

$* \mathrm{P}<0.05 ; * * \mathrm{P}<0.001 ; * * * \mathrm{P}<0.0001$.

We did not find significant differences in subcutaneous tissue deposition by measuring the UFAT (Table 5). We suggest that the small variation in the expression of the subcutaneous adipose tissue deposition within the GGs studied may have influenced the results of the contrasts between the means of comparison groups.

\section{Conclusion}

We show that growth traits and the Longissimus muscle area were affected by genetic $\mathrm{x}$ environment interactions. In addition, we found that the finished environment of both natural grassland and natural improved grassland in the Pampa Biome did not affect the deposition of subcutaneous tissue among the evaluated GGs.

\section{References}

BARLOW, R. Experimental evidence for interaction between heterosis and environment in animals. Animal Breeding Abstracts, Wallingford, v. 49, n. 11, p. 715-737, 1981.

BEAVER, E. E.; WILLIANS, J. E.; MILLER, S. J.; HANCOCK, D. L.; HANNAH, S. M.; O'CONNOR, D. L. Influence of breed and diet on growth, nutrient digestibility, body composition and plasma hormones of Brangus and Angus steers, Journal of Animal Science, Champaign, v. 67, n. 9, p. 2415-2425, 1989.

BERG, R. T.; BUTTERFIELD, R. M. New concepts of cattle growth. Sydney: University Press, 1976. 240 p. 
BRASIL. Ministério da Agricultura. Instrução Normativa $\mathrm{n}^{\circ} 9$ de maio de 2004. Sistema Brasileiro de Classificação de Carcaças de Bovinos. Diário Oficial [da] União, Brasília, 4 de maio de 2004. Seção 1, p. 3-4.

BROWN, M. A.; BROWN, A. H.; JACKSON, W. G.; MIESNER, J. R. Genotype x environment interactions in Angus, Brahman and reciprocal-cross cows and their calves grazing common bermudagrass, endophyteinfected tall fescue pastures or both forages. Journal of Animal Science, Champaign, v. 78, n. 3, p. 546-551, 2000.

CARDOSO, L. L.; BRACCINI NETO, J.; CARDOSO, F. F.; COBUCI, J. A.; BIASSUS, I. O.; BARCELLOS, J. O. J. Hierarchical Bayesian models for genotype $x$ environment estimates in post-weaning gain of Hereford bovine via reaction norms. Revista Brasileira de Zootecnia, Viçosa, MG, v. 40, n. 2, p. 294-300, 2011.

CASAS, E.; CUNDIFF, L. V. Postweaning growth and carcass traits in crossbred cattle from Hereford, Angus, Norwegian Red, Swedish Red and White, Friesian, and Wagyu maternal grandsires. Journal of Animal Science, Champaign, v. 84, n. 2, p. 305-310, 2006.

CASAS, E.; THALMANN, R. M.; KUEHN, L. A.; CUNDIFF, L. V. Postweaning growth and carcass traits in crossbred cattle from Hereford, Angus, Brangus, Beefmaster, Bonsmara, and Romosinuano maternal grandsires. Journal of Animal Science, Champaign, v. 88, n. 1, p. 102-108, 2010.

CORRÊA, M. B. B.; DIONELLO, N. J. L.; CARDOSO, F. F. Efeito da interação genótipo-ambiente na avaliação genética de Bovinos de corte. Revista Brasileira de Zootecnia, Viçosa, MG, v. 35, n. 3, p. 1005-1011, 2007.

CROUSE, J. D.; CUNDIFF, L. V.; KOCH, R. M.; KOOHMARAIE, M.; SEIDEMAN, S. C. Comparisons of Bos indicus and Bos taurus inheritance for carcass beef characteristics and meat palatability. Journal of Animal Science, Champaign, v. 67, n. 10, p. 2661-2668, 1989.

DE JONG, G.; BIJMA, P. Selection and phenotypic plasticity in evolutionary biology and animal breeding. Livestock Production Science, Amsterdam, v. 78, n. 3, p. 195-214, 2002.

DEVINCENZI, T.; NABINGER, C.; CARDOSO, F. F.; NALÉRIO, E. S.; CARASSAI, I. J.; FEDRIGO, J. K.; TAROUCO, J. U.; CARDOSO, L. L. Carcass characteristics and meat quality of Aberdeen Angus steers finished on different pastures. Revista Brasileira de Zootecnia, Viçosa, MG, v. 41, n. 4, p. 1051-1059, 2012.
DICKERSON, G. E. Implications of geneticenvironmental interaction in animal breeding. Animal Production, Bletchley, v. 4, n. 1, p. 47-63, 1962.

ETHERTON, T. D.; WALTON, P. E. Hormonal and metabolic regulation of lipid metabolism in domestic livestock. Journal of Animal Science, Champaign, v. 63, n. 2, p. 76-88, 1986.

EUCLIDES FILHO, K.; EUCLIDES, V. P. B.; FIGUEIREDO, G. R. de; OLIVEIRA, M. P. de. Avaliação de animais Nelore e de seus mestiços com Charolês, Fleckvieh e Chianina, em três dietas. 1. Ganho de peso e conversão alimentar. Revista Brasileira de Zootecnia, Viçosa, MG, v. 26, n. 1, p. 66-72, 1997.

FALCONER, D. S.; MACKAY, T. F. C. Introduction to quantitative genetics. $5^{\text {th }}$ ed. Edinburgh: Longman Group Limited, 1997. $480 \mathrm{p}$.

FERREIRA, E. T.; NABINGER, C.; ELEJALDE, D. A. G.; FREITAS, A. K.; SCMITT, F.; TAROUCO, J. U. Terminação de novilhos de corte Angus e mestiços em pastagem natural na região da Campanha do RS. Revista Brasileira de Zootecnia, Viçosa, MG, v. 40, n. 9, p. 2048-2057, 2011.

HAMLIN, K. E.; GREEN, R. D.; PERKINS, T. L.; CUNDIFF, L. V.; MILLER, M. F. Real-time ultrasonic measurement of fat thickness and longissimus mucle area: I. Description of age and weight effects. Journal of Animal Science, Champaign, v. 73, n. 6, p. 1713-1724, 1995.

KIPPERT, C. J.; RORATO, P. R.; LOPES, J. S.; WEBER, T.; BOLIGON, A. A. Efeitos genéticos aditivos diretos e maternos e heterozigóticos sobre os desempenhos pré e pós-desmama em uma população multirracial Aberdeen Angus x Nelore. Revista Brasileira de Zootecnia, Viçosa, MG, v. 37, n. 8, p. 1383-1391, 2008.

LAGE, J. F.; PAULINO, P. V. R.; VALADARES FILHO, S. C.; SOUZA, E. J. O.; DUARTE, M. S.; BENEDETI, P. D. B.; SOUZA, N. K. P.; COX, R. B. Influence of genetic type and level of concentrate in the finishing diet on carcass and meat quality traits in beef heifers. Meat Science, Barking, v. 90, n. 3, p. 770-774, 2012.

LAWRIE, R. A. Meat science. $6^{\text {th }}$ ed. Porto Alegre: Artmed, 2004. 384 p.

LIU, Y. Auskey for Windows Version 5.00, Animal Ultrasound Services Inc, Users Manual. New York: Animal Ultrasound Services, 1997. 192 p. 
LOPES, J. S.; RORATO, P. R. N.; WEBER, T.; BOLIGON, A. A.; COMIN, J. G.; DORNELLES, M. A. Efeito da interação genótipo $\mathrm{x}$ ambiente sobre o peso ao nascimento aos 205 e aos 550 dias de idade de bovinos da raça Nelore na Região Sul do Brasil. Revista Brasileira de Zootecnia, Viçosa, MG, v. 37, n. 1, p. 54-60, 2008.

MERSMANN, H. J. Metabolic and endocrine control of adipose tissue accreation. In: WOOD, J. D.; FISHER, A. V. Reducing fat in meat animals. London: Elsevier Applied Science, 1990. p. 101-144.

NATIONAL RESEARCH COUNCIL - NRC. Nutrient requirements of dairy cattle. $7^{\text {th }} \mathrm{ed}$. Washington: National Academy Press, 2001. 242 p.

OWENS, F. N.; DUBESKI, P.; HANSON, C. F. Factors that alter the growth and development of ruminants. Journal of Animal Science, Champaign, v. 71, n. 11, p. 3138-3150, 1993.

PEROTTO, D.; MOLETTA, J. L.; ABRAHÃO, J. J. S.; PAULA, M. C. Características da carcaça e da carne de bovinos Nelore e cruzados Bos taurus x Bos indicus. In: SIMPÓSIO BRASILEIRO DE MELHORAMENTO ANIMAL, 7., 2008, São Carlos. Anais... São Carlos: Embrapa Pecuária Sudeste, 2008. CD-ROM.

PRADO, C. S.; PÁDUA, J. T.; CORRÊA, M. P. C.; FERRAZ, J. B. S.; MIYGI, E. S.; RESENDE, L. S. de. Comparação de diferentes métodos de avaliação da área de olho de lombo e cobertura de gordura em bovinos de corte. Ciência Animal Brasileira, Goiânia, v. 5, n. 3, p. 141-149, 2004.
QUEIROZ, S. A.; COSTA, G. Z.; OLIVEIRA, J. A. de; FRIES, L. A. Efeitos ambientais e genéticos sobre escores visuais e ganho de peso à desmama de animais formadores da raça Brangus. Revista Brasileira de Zootecnia, Viçosa, MG, v. 38, n. 2, p. 277-283, 2009.

SIQUEIRA, F.; TORRES JUNIOR, R. A. de A.; REGITANO, L. C. deA.; ALENCAR, M. M.; GOUVEIA, J. J.; CERVINI, M. Diversidade genética de bovinos de corte por meio de marcadores microssatélites. In: REUNIÃO ANUAL DA SOCIEDADE BRASILEIRA DE ZOOTECNIA, 46., 2009, Maringá. Anais... Maringá: Sociedade Brasileira de Zootecnia, 2009. CD-ROM.

TE PAS, M. F. W.; EVERTS, M. E.; HAAGSMAN, H. P. Muscle development of livestock animals: physiology, genetics, and meat quality. Cambridge: CABI, 2004. 411 p.

TEIXEIRA, R. A. de.; ALBUQUERQUE, L. G.; ALENCAR, M. M. de.; DIAS, L. T. Interação genótipoambiente em cruzamentos de bovinos de corte. Revista Brasileira de Zootecnia, Viçosa, MG, v. 35, n. 4, p. $1677-$ 1683, 2006.

VAZ, F. N.; RESTLE, J. Efeito de raça e heterose para características de carcaça de novilhos da primeira geração de cruzamento entre Charolês e Nelore. Revista Brasileira de Zootecnia, Viçosa, MG, v. 30, n. 2, p. 409416, 2001. 
